\title{
Transformed Small Lymphocytic Lymphoma to Diffuse Large B-Cell Lymphoma
}

National Cancer Institute

\section{Source}

National Cancer Institute. Iransformed Small Lymphocytic Lymphoma to Diffuse Large

B-Cell Lymphoma. NCI Thesaurus. Code C157625.

Histologic transformation of an indolent small lymphocytic lymphoma to an aggressive diffuse large B-cell lymphoma. 